\title{
Immunrekonstitusjonssyndrom ved behandling av hivinfeksjon
}

\author{
Sammendrag \\ Bakgrunn. Høyaktiv antiretroviral terapi \\ (HAART) forårsaker ikke sjelden en \\ paradoksal reaksjon på latente infeksjo- \\ ner $\mathrm{i}$ forbindelse med at immunsystemet \\ regenererer, såkalt immunrekonstitu- \\ sjonssyndrom. I artikkelen gis en over- \\ sikt over syndromet, med vekt på dia- \\ gnostikk, risikofaktorer og praktisk \\ håndtering.
}

\section{Materiale og metode. Oversikten er basert på klinisk erfaring og artikler funnet ved ikke-systematiske søk i PubMed.}

Resultater. Immunrekonstitusjonssyndrom oppstår gjerne noen uker eller måneder etter oppstart av HAARTbehandling og er hyppigst beskrevet ved infeksjon med mykobakterier, cytomegalovirus, Cryptococcus neoformans og Pneumocystis jirovecii. I utgangspunktet kan enhver latent infeksjon forårsake en slik immunreaksjon. Risikofaktorer er uttalt immunsvikt ved behandlingsstart, stor mengde infeksiøst agens og rask immunologisk respons på HAART-regimet. Prognosen er god. Infeksjonsutredning og terapi må imidlertid ikke forsinke oppstart av HAARTbehandling hos immunkompromitterte pga. risikoen for $ø$ kt mortalitet og morbiditet. Behandlingen bør fortsette selv om tilstanden manifesterer seg, og kun ved livstruende situasjoner eller lokalt destruerende prosesser bør HAARTregimet forbigående seponeres. Kortikosteroider kan ha god effekt ved lesjoner i sentralnervesystemet, obstruerende lymfeknuter eller økende respiratoriske symptomer.

Fortolkning. De siste årenes behandlingssuksess ved hivinfeksjon medfører at flere kan utvikle immunrekonstitusjonssyndrom. Rask diagnostikk av opportunistiske infeksjoner og igangsetting av adekvat behandling er viktig for prognosen.

\author{
Marius Trøseid \\ troseid@hotmail.com \\ Medisinsk avdeling \\ Oslo universitetssykehus, Ullevål \\ og \\ Leger Uten Grenser \\ Postboks 8813 Youngstorget \\ 0028 Oslo

\section{Arne Eskesen} \\ Infeksjonsmedisinsk seksjon \\ Akershus universitetssykehus

\section{Johan N. Bruun} \\ Infeksjonsmedisinsk seksjon \\ Universitetssykehuset Nord-Norge \\ og \\ Institutt for klinisk medisin \\ Universitetet i Troms $\varnothing$
}

De siste årene har rutinemessig bruk av HAART-behandling gjort hivinfeksjon i vestlige land til en kronisk sykdom. En god prognose forutsetter imidlertid nær $100 \%$ medikamentetterlevelse, og utfordringene er store når det gjelder bivirkninger som lipodystrofi, endret lipidprofil og mitokondrietoksisitet (1).

En annen utfordring er at latente infeksjoner kan manifestere seg eller at manifeste opportunistiske infeksjoner forverres når immunsystemet regenererer - såkalt immunrekonstitusjonssyndrom (2-5). Et tilsvarende sykdomsbilde kan også oppstå hos andre med immunsvikt - «paradoks reaksjon» i forbindelse med tuberkulosebehandling representerer det samme fenomenet (2).

Immunrekonstitusjonssyndrom er hyppigst beskrevet ved infeksjoner med mykobakterier, cytomegalovirus (CMV), Cryptococcus neoformans og Pneumocystis jirovecii. Også JC-virus, hepatitt B-, hepatitt Cog varicella zoster-virus er velkjente årsaker.

I utgangspunktet kan enhver latent infeksjon forårsake en slik immunreaksjon $(2-5)$. Syndromet er også beskrevet i forbindelse med autoimmune sykdommer, sarkoidose og maligne sykdommer som lymfom og Kaposis sarkom $(4,5)$. Hvorvidt de sistnevnte er en reaksjon på tumorantigener eller tumorrelaterte infeksiøse agenser, som Epstein-Barr-virus og humant herpesvirus 8, er ikke avklart (4).

Vi gir her en oversikt over syndromet, med vekt på diagnostikk, risikofaktorer og praktisk håndtering. Siden det kliniske bildet varierer med de ulike latente infeksjonene, vil vi beskrive de hyppigste infeksjonene i egne avsnitt.

\begin{abstract}
Materiale og metode
Artikkelen er basert på ikke-systematiske litteratursøk i PubMed. I mangel av veldesignede randomiserte, kontrollerte studier har vi vektlagt nyere oversiktsartikler, retrospektive studier og ekspertuttalelser som referansegrunnlag for vår oversiktsartikkel, i tillegg til kliniske erfaringer fra arbeid i inn- og utland.
\end{abstract}

\section{Diagnostikk og risikofaktorer}

Definisjonen av immunrekonstitusjonssyndrom varierer betydelig, og det er foreløpig ingen konsensus om de diagnostiske kriteriene. De fleste definisjoner krever imidlertid tilstedeværelse av:

- En latent infeksjon

- En målbar bedring i CD4-tall eller et tilsvarende fall i virusmengde etter oppstart av HAART-behandling

- Sammenheng i tid mellom behandlingsstart og klinisk bilde forenlig med syndromet

- Utelukkelse av andre årsaker - medikamentbivirkninger, dårlig medikamentetterlevelse eller nyoppstått infeksjon $(2-6)$

Rask og riktig diagnostikk av opportunistiske infeksjoner hos pasienter med immunsvikt er viktig, men utfordrende, siden forløpet ofte er subklinisk. Det kan dessuten være vanskelig å avgjøre om en opportunistisk infeksjon er nyoppstått eller om den har ligget latent og først gir symptomer etter start av HAART-behandling. Tidsaspektet kan i slike tilfeller være til hjelp, da immunrekon-

\section{Hovedbudskap}

- Immunrekonstitusjonssyndrom er en komplikasjon til HAART-behandling

- Risikofaktorer er uttalt immunsvikt, stor mengde infeksiøst agens og rask immunologisk respons. Prognosen er god

- Rask diagnostikk og behandling av opportunistiske infeksjoner er viktig for å forebygge immunrekonstitusjonssyndrom

- Kortikosteroider kan ha god effekt ved lesjoner i sentralnervesystemet, obstruerende lymfeknuter eller økende respiratoriske symptomer 
stitusjonssyndrom hyppigst oppstår et par uker til tre måneder etter oppstarten (3-5). Tilstanden kan dessuten mistenkes ved atypiske sykdomsbilder, som sjeldne lokalisasjoner eller uventet forverring på tross av adekvat behandling av infeksjonen (4). I denne forbindelse er det viktig å gjøre dyrkingsundersøkelser med resistensbestemmelse for å utelukke behandlingssvikt (4). Dyrkinger kan imidlertid være negative, siden inflammasjonsreaksjonen også kan rettes mot antigener fra døde organismer (5). Utredning med bildediagnostikk, histologiske undersøkelser, antigentester og genteknologisk påvisning av agenser fra eksempelvis biopsier og bronkial skyllevæske kan i slike tilfeller være til hjelp.

Medikamentbivirkninger og hypersensitivitetsreaksjoner kan også gi et liknende sykdomsbilde (4), men symptomene vil da typisk komme etter hver medikamentdose og bli mildere før neste dose, i motsetning til ved immunrekonstitusjonssyndrom, hvor symptomene vedvarer.

En forutsetning for å stille diagnosen er å være oppmerksom på tilstanden hos utsatte pasienter. En betydelig risikofaktor er uttalt immunsvikt ved behandlingsstart $(2-8)$. Andre risikofaktorer er lav alder ved start av behandling (7) og stor mengde infeksiøst agens (2). Graden av immunrekonstitusjon (2-6) og fall i virusmengde (8) ser også ut til å være av betydning. I en retrospektiv studie med pasienter med behandlet tuberkulose var økning i CD4-tall og CD4-CD8-ratio assosiert med forekomst av syndromet (9).

\section{Insidens og prognose}

Insidensen av immunrekonstitusjonssyndrom varierer antakelig med forekomsten av opportunistiske infeksjoner og CD4-cellenivå ved diagnosetidspunktet (4). I retrospektive studier med pasienter fra ulike vestlige land varierte insidensen fra $17 \%$ til $25 \%$, mens den var $32 \%$ i en retrospektiv studie med amerikanske pasienter med diagnostiserte opportunistiske infeksjoner ved behandlingsstart (4). Sannsynligvis ligger den reelle insidensen i vestlige land betydelig lavere, kanskje på 5-10\% (10). I en nyere prospektiv studie fra Sør-Afrika forekom immunrekonstitusjonssyndrom hos rundt $10 \%$ av pasientene i løpet av seks måneders observasjonstid etter oppstart av HAART-behandling (11).

Prognosen er vanligvis god, selv om langtidssekveler kan forekomme, spesielt hvis det er affeksjon av sentralnervesystemet (3, 5). Den rapporterte mortaliteten relatert til tilstanden er lav, og i de tre største retrospektive studiene fra vestlige land ble det registrert $\mathrm{i}$ alt to dødsfall blant 142 pasienter (12). I en prospektiv studie fra Sør-Afrika ble det registrert to dødsfall blant 44 pasienter med immunrekonstitusjonssyndrom (11). Sannsynligvis er både morbiditet og mortalitet underrapportert i utviklingsland, og spesielt immunrekonstitusjonssyndrom- relatert kryptokokkmeningitt kan forårsake betydelig dødelighet $(4,5,12)$.

\section{Patogenese}

Stigningen i CD4-tall etter behandlingsstart følger vanligvis et bifasisk forløp $(2,3)$. En rask økning av sirkulerende CD4-celler forekommer de første 3-6 månedene, og man antar at dette i hovedsak skyldes redusert apoptose og samtidig redistribusjon av lymfocytter fra lymfoid vev. Deretter skjer det en mer gradvis økning i CD4-tallet, med nydannede CD4-celler fra eksisterende Tcellekloner $(2,3)$. De fleste tilfeller av immunrekonstitusjonssyndrom forekommer i den første fasen av immunrekonstitusjonen, selv om enkelte har rapportert tilstedeværelse av mulig syndrom inntil fire år etter behandlingsstart $(2,3,6)$. Immunresponsen kan rettes mot både levende og døde organismer, og kan gi en voldsom reaksjon dersom antigenmengden er stor $(2,6)$.

Sentralt i utviklingen av syndromet er gjenvinning av cellulær immunrespons, men patogenesen varierer, trolig avhengig av utløsende agens (5). Ved virusutløst immunrekonstitusjonssyndrom domineres inflammasjonsreaksjonen av CD8-celler $(5,6)$. Hvis det er forårsaket av mykobakterier og soppinfeksjoner, er inflammasjonsreaksjonen ofte assosiert med en T-hjelper 1-immunrespons (Th1), med økt produksjon av interferon- $\gamma$, som sammen med kjemokiner og proinflammatoriske cytokiner aktiverer mononukleære celler til granulomdanning $(5,6)$.

Genetisk variasjon og predisposisjon er sannsynligvis også involvert. Man har blant annet funnet en overhyppighet av polymorfismer i gener for ulike cytokiner og HLAmolekyler hos pasienter med immunrekonstitusjonssyndrom $(13,14)$. Foreløpig er det imidlertid ikke avklart hvilken rolle disse potensielle mekanismene spiller $(2,4,6)$.

\section{Klinisk bilde ved de hyppigste infeksjonene} Tuberkulose

Koinfeksjon med hiv og tuberkulose er et stort problem på verdensbasis og hyppigste dødsårsak hos hivpositive (15). I en sørafrikansk kohort var det nylig diagnostisert eller behandlet tuberkulose hos $25 \%$ ved oppstart av HAART-behandling og en insidensrate på 23 per 100 personår i løpet av de første tre månedene av behandlingen (16). Immunrekonstitusjonssyndrom forekommer hos $8-43 \%$ av dem med kjent tuberkulose ved oppstart av HAART-behandling (17). I en gjennomgang av 86 kasuistikker fant man at median varighet fra behandlingsstart til oppstått immunrekonstitusjonssyndrom var fire uker, mens mediant CD4-tall var $51 \cdot 10^{6} / 1$ (6).

De vanligste symptomene er feber, vekttap, forverring av respiratoriske symptomer og progrediering av røntgenologiske forandringer. Ekstrapulmonal tuberkulose er imid- lertid hyppig forekommende blant hivpositive, og immunrekonstitusjonssyndrom kan manifestere seg i lymfeknuter, sentralnervesystemet, urinveier, abdomen og hud og gi opphav til en lang rekke symptomer. Paradoks hyperkalsemi er også beskrevet, og kan antakelig skyldes blant annet utskilling av 1,25-dihydroksykolekalsiferol fra tuberkuløse granulomer $(6,18)$. Diagnostikk av lungetuberkulose hos hivpositive kan være vanskelig av flere grunner. Spesielt pasienter med lavt CD4-tall har oftere sputumnegativ tuberkulose og få eller ingen forandringer på røntgen thorax $(19,20)$. Dyrking og PCRundersøkelse av bronkial skyllevæske kan være nødvendig for å stille diagnosen. I utviklingsland må man ofte starte behandling ut fra det kliniske bildet alene.

\section{Atypiske mykobakterier}

Mycobacterium avium-intracellularkompleks er hyppigst forekommende hos pasienter med svært uttalt immunsvikt. I de fleste tilfeller med immunrekonstitusjonssyndrom er infeksjonen ikke diagnostisert før oppstart av HAART-behandling, som illustrert i kasuistikken nedenfor (6). I en gjennomgang av 64 kasuistikker fant man at median tid fra behandlingsstart til utvikling av immunrekonstitusjonssyndrom var fire uker, mens mediant CD4-tall var $25 \cdot 10^{6} / 1$ (6). De hyppigst forekommende symptomene er feber og ofte uttalt glandelsvulst, men affeksjon av skjelett, muskulatur, abdomen og sentralnervesystem er rapportert $(3,6)$.

Pasienten. En 46 år gammel mann ble innlagt med nyoppdaget hivinfeksjon og alvorlig immunsvikt, med CD4-tall på 6-106/l. Han fikk initialt behandling med høydose trimetoprim-sulfa grunnet pneumoni med Pneumocystis jirovecii. Dette ble seponert pga. utslett og feber rundt $38^{\circ} \mathrm{C}$, men temperaturen gikk ikke ned. Man gjorde omfattende diagnostiske utredninger, inkludert mykobakteriedyrking fra blod og feces, uten å påvise andre opportunistiske infeksjoner. CT abdomen viste imidlertid multiple lett forstørrede glandler paraaortalt. Tre uker etter oppstart av HAART-behandling ble han på nytt innlagt med feber på $39^{\circ} \mathrm{C}$, anemi og vekttap. CT abdomen viste betydelig økning $i$ antall lymfeknuter og lymfeknutestørrelse (fig 1), og man påviste nå Mycobacterium avium-intracellularkompleks i dyrkinger fra lymfeknutebiopsi, blod, beinmarg og feces. Man fortsatte HAART-behandlingen og startet med ciprofloksacin, klaritromycin og etambutol. Etter ti dager var pasienten afebril, med økende vekt og stigende hemoglobinverdi. CD4-tallet var $30 \cdot 10^{6} / \mathrm{l}$. Etter fire måneders behandling var det steget til $100 \cdot 10^{6} / l$.

Sentralt i diagnostikken er dyrking av blodkultur, beinmarg og affiserte lymfeknuter, som beskrevet over. I utviklingsland er dyrkingsundersøkelser stort sett ikke tilgjenge- 


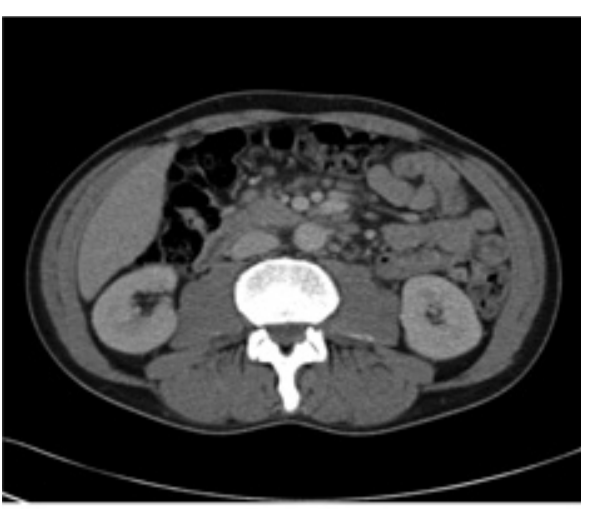

a

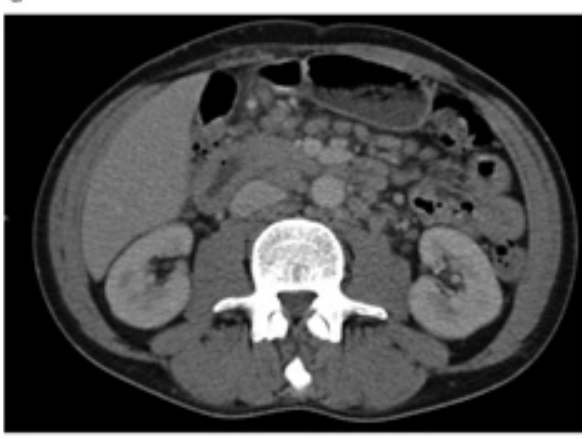

b

Figur 1 CT abdomen tatt al før behandlingsstart og b) noen uker etter oppstart av antiretroviral behandling. Man kan se en betydelig økning i både antall lymfeknuter og størrelsen på disse

lig, men syrefaste staver kan i en del tilfeller påvises ved mikroskopi av direkte preparater fra punktater, farging av «buffy-coat» eller avføringsprøve. Av og til må man imidlertid gjøre et diagnostisk behandlingsfors $ø \mathrm{k}$ på klinisk mistanke. Et poeng i denne sammenheng er at etambutol ikke inngår i de fleste nasjonale behandlingsprotokoller mot tuberkulose utover de to første månedene, og at andre aktuelle medikamenter som ciprofloksacin og klaritromycin ofte må spesialbestilles.

\section{Cytomegalovirus}

Cytomegalovirus (CMV) forårsaker oftest retinitt og uveitt i forbindelse med HAARTbehandling, selv om også andre organer kan affiseres $(2,10)$. Retinitt forekommer oftest i løpet av de tre første månedene, mens uveitt kan oppstå mye senere i forløpet (21, 22). Graden av immunrekonstitusjonsrelatert CMV-uveitt er ikke korrelert med CD4tall, i motsetning til CMV-retinitt, som fortrinnsvis ofte oppstår ved CD4-tall $<100 \cdot 10^{6} / 1$ (2). Mekanismene er ikke avklart, men Th2-effektorceller ser ut til å være involvert i patogenesen $(5,23,24)$.

Hos pasienter med uttalt immunsvikt er det viktig å være oppmerksom på symptomer som endret visus, nedsatt synsfelt, smerter i øynene eller synsfenomener som lysglimt eller flytende objekter i synsfeltet. Ved oftalmoskopi kan man ofte se en intens inflammatorisk reaksjon (25). Det er viktig å informere øyelegen om den kliniske mistanken og problemstillingen.

\section{Cryptococcus neoformans}

Cryptococcus neoformans er en sopp som som regel gir infeksjon hos pasienter med svært uttalt immunsvikt. Også immunrekonstitusjonssyndromrelatert kryptokokkinfeksjon er beskrevet $i$ én tidlig og én sen variant. Meningoencefalitt manifesterer seg ofte tidlig, mens det kan ses residiv av meningitt, lymfadenitt og kryptokkom, eventuelt med abscedering i hud, mediastinum, lunger og sentralnervesystem, fra uker til mange måneder etter oppstart av HAART-behandling (26-28).

Feber, hodepine, kvalme og nakkestivhet er vanlige symptomer ved meningoencefalitt, og ved spinalpunksjon er det viktig å måle åpningstrykket, som ofte er svært forhøyet $(27,28)$. Ved klassisk kryptokokkmeningitt skyldes dette sannsynligvis nedsatt drenasje av cerebrospinalvæske grunnet mekanisk blokkering forårsaket av store mengder kryptokokker og deres polysakkarider (27). Ved immunrekonstitusjonssyndrom kan en inflammasjonsreaksjon mot antigener i hjernehinnene også spille en rolle (29). Et forhøyet åpningstrykk (>20 cm vann) ved spinalpunksjon styrker den kliniske mistanken om kryptokokkmeningitt. Diagnosen stilles ved mikroskopi av tusjfargepreparat eller ved antigenundersøkelse av spinalvæske (27).

\section{Pneumocystis jirovecii}

Det er velkjent at mange pasienter kan få en paradoksal reaksjon ved antibiotikabehandling av Pneumocystis jirovecii, med dyspné, hypoksi, hoste, feber og økende diffuse bilaterale lungefortetninger. Ved immunrekonstitusjonssyndromrelatert pneumocystisinfeksjon er symptomer og funn de samme, og tilstanden kan mistenkes når symptomene er tidsmessig mer relatert til oppstart av HAART-behandling enn til påbegynt antibiotikabehandling (3). Det typiske bildet er en pasient som under behandling for Pneumocystis jirovecii får klinisk forverring 1-3 uker etter oppstart av HAART-behandling.

Inflammasjonsreaksjonen kan både skyldes frigjøring av antigener på grunn av selve behandlingen og økt immunreaksjon ved samtidig oppstart av HAART-behandling. Ved bronkoskopi kan man ofte se rikelig med betennelsesceller i bronkial skyllevæske, og Pneumocystis jirovecii kan påvises ved direkte immunfluorescens eller PCR $(3,30)$. I utviklingsland må man oftest behandle ut fra det kliniske bildet og funn på røntgen thorax.

\section{Terapianbefalinger}

I mangel av randomiserte studier bygger våre anbefalinger på ekspertuttalelser, observasjonelle studier og egne erfaringer.

\section{Behandling av opportunistiske infeksjoner}

Det er viktig å diagnostisere og behandle enhver opportunistisk infeksjon så raskt og så riktig som mulig, for å redusere antigenmengden og for om mulig å forebygge utvikling av immunrekonstitusjonssyndrom. Det er viktig å utelukke andre årsaker til symptomene, f.eks. medikamentbivirkninger, hypersensitivitetsreaksjoner og manglende medikamentetterlevelse (1-4). For detaljer om diagnostikk og behandling av de ulike opportunistiske infeksjoner henvises det til egen litteratur.

\section{HAART-behandling}

Hovedregelen er at man fortsetter med HAART-behandling på tross av immunrekonstitusjonssyndrom $(2,3,5)$. Det er svært viktig med hyppige kontroller med tanke på bivirkninger og medikamentetterlevelse, og pasienten må informeres om at medikamentene virker og at prognosen er god til tross for ubehagelige symptomer. Kun ved livstruende tilstander eller destruerende lokaliserte prosesser som ikke svarer på steroidbehandling bør HAART-regimet forbigående seponeres $(2,3,5)$.

Det er ingen konsensus om når man skal sette i gang HAART-behandling når en opportunistisk infeksjon er diagnostisert. Noe tids behandling av den opportunistiske infeksjonen vil redusere antigenmengden og kan i teorien forebygge utvikling av immunrekonstitusjonssyndrom, samtidig som risikoen for nye aidsdefinerende sykdommer og død øker $(2,5)$. En nylig publisert studie med hovedsakelig amerikanske pasienter stratifisert etter CD4-tall (< eller > 50 $10^{6}$ / 1) og opportunistiske infeksjoner (tuberkulose ekskludert) sammenliknet tidlig oppstart av HAART (median 12 dager) med avventende behandling (median 45 dager) (31). Pasienter som ble randomisert til tidlig behandling hadde signifikant færre dødsfall og aidsdefinerende sykdommer enn pasienter i gruppen med forsinket behandling (31). Inntil flere studier er publisert taler mye for tidlig HAART-behandling av pasienter med opportunistisk infeksjon dersom det ikke foreligger kontraindikasjoner $(5,31$, 32).

Ett mulig unntak kan være infeksjoner i sentralnervesystemet, og spesielt kryptokokkmeningitt. I en nylig presentert studie fra Zimbabwe, der 54 pasienter med denne sykdommen ble randomisert til tidlig HAART-behandling (innen tre døgn) eller HAART-behandling etter ti uker med flukonazolbruk, var mortaliteten etter to år signifikant høyere i gruppen med tidlig behandling enn i gruppen som fikk sen (Makadzange A, Ndhlovu C, Takarinda K et al. Early vs delayed ART in the treatment of cryptococcal meningitis in Africa. $16^{\text {th }}$ Conference on Retroviruses and Opportunistic infections. Montreal, februar 2009. Abstract No 36cLB). Dette var overraskende resultater, og nye studier av tidlig versus sen HAARTbehandling ved ulike typer opportunistiske infeksjoner, inkludert kryptokokkmeningitt og tuberkuløs meningitt, er nå satt $\mathrm{i}$ gang $\mathrm{i}$ 
flere utviklingsland (Philip Grant, personlig meddelelse).

Koinfeksjon med hiv og tuberkulose kompliseres på grunn av risiko for immunrekonstitusjonssyndrom, overlappende medikamentbivirkninger og medikamentinteraksjoner, spesielt de to første månedene av tuberkulosebehandlingen (13). To retrospektive studier viser imidlertid at selv om behandlingen kan utsettes $\mathrm{i}$ inntil to måneder hos dem med CD4tall $>100 \cdot 10^{6} / 1$, er det økt mortalitet og morbiditet hos pasienter med CD4-tall $<100 \cdot 10^{6} / 1$ ved sen behandling $(33,34)$. I utviklingsland er dødeligheten klart høyere hos dem med avansert hivsykdom, og en avventende strategi kan være ekstra uheldig i denne forbindelse $(5,6)$. Inntil flere studier er publisert taler mye for tidlig HAART-behandling hos pasienter med tuberkulose og lavt CD4tall $(6,35)$. Ifølge nasjonale retningslinjer bør man avvente to ukers tuberkulosebehandling før oppstart av HAART-behandling ved CD4tall $<100 \cdot 10^{6} / 1$, åtte ukers behandling ved CD4-tall 100-350 $\cdot 10^{6} / 1$ og fullført behandling ved CD4-tall $>350 \cdot 10^{6} / 1(36)$.

\section{Antiinflammatorisk behandling}

Kortikosteroidbehandling kan ha god effekt ved lesjoner i sentralnervesystemet (2), obstruerende lymfeknuter (3) eller økende luftveissymptomer, spesielt hos pasienter med mykobakterieinfeksjon eller Pneumocystis jirovecii $(6,30)$. Prednisolon $1 \mathrm{mg} / \mathrm{kg} / \mathrm{dag}$ (maksimalt 60-80 mg daglig) eller deksametason $8-16 \mathrm{mg} / \mathrm{dag}$ (fordelt på to doser) $\mathrm{i}$ noen uker med gradvis nedtrapping etter klinisk respons over 10-14 dager kan forsøkes $(3,6)$.

Kortikosteroider er imidlertid assosiert med overhyppighet av Kaposis sarkom og reaktivering av herpesinfeksjoner hos hivpasienter, og dersom diagnosen er gal, er det en risiko for maskering og forverring av ubehandlede opportunistiske infeksjoner (4). Ved kryptokokkmeningitt med forhøyet intrakranialt trykk er bruk av kortikosteroider omdiskutert $(2,4,5,27)$. En større observasjonell studie viste økt mortalitet ved høydose steroidbehandling, mens gjentatte spinalpunksjoner med drenasje av spinalvæske var trygt og derfor anbefalt $\mathrm{i}$ amerikanske retningslinjer $(27,37)$. Ved immunrekonstitusjonssyndromrelatert kryptokokkmeningitt er patogenesen sannsynligvis mer preget av inflammerte hjernehinner enn av mekanisk blokkering, og steroider har vært brukt med hell ved residiv av meningitt og tegn til økt inflammasjonsrespons $(28,38)$. Noen eksperter anbefaler symptomatisk behandling av immunrekonstitusjonssyndrom med ikke-steroide antiinflammatoriske midler (NSAID), men det er begrenset dokumentasjon for dette $(2,36,39)$.

Pasienten har gitt samtykke til at artikkelen blir publisert.
Litteratur

Bruun JN, Skeie L, Mæland A et al. Fra dødelig syndrom til kronisk sykdom. Tidsskr Nor Lægeforen 2006: 126: 3121-4.

2. Lipman M, Breen R. Immune reconstitution inflammatory syndrome in HIV. Curr Opin Infect Dis 2006; 19: $20-5$.

3. Sexton DJ, Pien B. Immune reconstitution inflammatory syndrome. www.uptodate.com (31.1.2008)

4. Dhasmana DJ, Dheda K, Ravn P et al. Immune reconstitution inflammatory syndrome in HIVinfected patients receiving antiretroviral therapy. Pathogenesis, clinical manifestetions and management. Drugs 2008; 68: 191-208.

5. French MA. Immune reconstitution inflammatory syndrome: a reappraisal. Clin Infect Dis 2009; 48: $101-7$.

6. Lawn SD, Bekker LG, Miller RF. Immune reconstitution disease associated with mycobacterial infections in HIV-infected individuals receiving antiretrovirals. Lancet Infect Dis 2005; 5: 361-73.

7. Ratnam I, Chiu C, Kandala NB et al. Incidence and risk factors for immune reconstitution inflammatory syndrome in an ethnically diverse HIV type-1 infected cohort. Clin Infect Dis 2006; 42: 418-27.

8. Manabe YC, Campbell JD, Sydnor E et al. Immune reconstitution inflammatory syndrome: risk factors and treatment implications. J Acquir Immune Defic Syndr 2007; 46: 456-62.

9. Breton G, Duval X, Estella C et al. Determinants of immune reconstitution inflammatory syndrome in HIV type 1-infected patients with tuberculosis after antiretroviral therapy. Clin Infect Dis 2004; 39: 1709-12.

10. Hoffmann C. Immune reconstitution inflammatory syndrome (IRS). HIV Medicine 2007; 15. utg.: 458-62. www. hivmedicine.com (10.6.2008).

11. Murdoch DM, Venter WD, Feldman C et al. Incidence and risk factors for the immune reconstitution inflammatory syndrome in HIV patients in South Africa: a prospective study. AIDS 2008; 22 $601-10$

12. Elston JW, Thaker H. Immune reconstitution inflammatory syndrome. Int J STD AIDS 2009; 20 : $221-4$

13. Price $P$, Keane NM, Stone SF et al. MHC haplotypes affect the expression of opportunistic infections in HIV patients. Hum Immunol 2001; 62 : $157-64$

14. Price P, Morahan G, Huang D et al. Polymorphisms in cytokine genes define subpopulations of HIV-1 patients who experienced immune restoration diseases. AIDS 2002; 16: 2043-47

15. Trøseid M, Handal N, Holen $\emptyset$. Tuberkulose - den glemte delen av hivepidemien. Tidsskr Nor Lægeforen 2007: 127: 2712-4

16. Lawn SD, Myer L, Bekker LG et al. Burden of tuberculosis in an antiretroviral treatment programme in sub-Saharan Africa: impact on treatment outcomes and implications for tuberculosis control. AIDS 2006: 20: 1605-12.

17. Lawn SD, Wilkinson RJ, Lipman MC et al. Immune reconstitution and «unmasking» of tuberculosis during antiretroviral therapy. Am J Respir Crit Care Med 2008: 177: 680-5.

18. Gkonos PJ, London R, Hendler ED. Hypercalcemia and elevated 1,25-dihydroxyvitamin D levels in a patient with end-stage renal disease and active tuberculosis. N Engl J Med 1984; 311: 1683-5.

19. Mgusi M, Villamor E, Urassa W et al. HIV co-infection, CD4 cell counts and clinical correlates of bacillary density in pulmonary tuberculosis. Int J Tuberc Lung Dis 2006; 10: 663-9.

20. Perlman DC, el-Sadr WM, Nelson ET et al. Variation of chest radiographic patterns in pulmonary tuberculosis by degree of human virus-related immunosuppression. Clin Infect Dis 1997; 25: $242-6$

21. Karevellas MP, Azen SP, Macdonal JC et al. Immune recovery vitritis and uveitis in AIDS clinical predictors, sequelae, and treatment outcomes. Retina 2001; 21: 1-9.

22. Wright ME, Suzman DL, Csaky KG et al. Extensive retinal neovascularisation as a late finding in human immunodeficiency virus-infected patients with immune recovery uveitis. Clin Infect Dis 2003 36: $1063-6$.

23. Stone SF. Price P. Tay-Kearney ML et al. Cytomegalovirus (CMV) retinitis restoration disease occurs during highly active antiretroviral therapyinduced restoration of CMV-specific immune responses within a predominant Th2 cytokine environment. J Infect Dis 2002; 185: 1813-7.

24. Hsieh SM, Pan SC, Hung CC et al. Association between cytomegalovirus-specific reactivity of $T$ cell subsets and development of cytomegalovirus retinitis in patients with acquired immunodeficiency syndrome. J Infect Dis 2001; 184: 1386-91.

25. Jacobson MA, Zegans M, Pavan PR et al. Cytomegalovirus retinitis after initiation of highly active antiretroviral therapy. Lancet 1997: 349: 1443-5.

26. Jenny-Avital ER, Abadi M. Immune reconstitution cryptococcosis after initiation of successful highly active antiretroviral therapy. Clin Infect Dis 2002; 35: e128-e133.

27. Saag M, Graybill RJ, Larsen RA et al. Practice guidelines for the management of cryptococcal disease. Infectious Diseases Society of America. Clin Infect Dis 2000: 30: 710 -8.

28. Blanche P, Gombert B, Ginsburg C et al. HIV com bination therapy: immune restitution causing cryptococcal lymphadenitis dramatically improved by anti-inflammatory therapy. Scand $J$ Infect Dis 1998; 30: 615-6

29. Boelaert JR, Goddeeris KH, Vanopdenbosch LJ et al. Relapsing meningitis caused by persistent cryptococcal antigens and immune reconstitution after the initiation of highly active antiretroviral therapy. AIDS 2004: 18: 1223-4

30. Wislez M, Bergot E, Antoine M et al. Acute respiratory failure following HAART introduction in patients treated for Pnemocystis carinii pneumonia. Am J Respir Crit Care Med 2001; 164: 847-51.

31. Zolopa A, Andersen J, Powderly W et al. Early antiretroviral therapy reduces AIDS progression/death in individuals with acute opportunistic infections: a multicenter randomized strategy trial. PLoS One 2009; 4: e5575.

32. Grant P. Zolopa A. Initiation of antiretroviral therapy in the hospitalised patient with an acute AIDS related opportunistic infection and other conditions: no time to lose. Curr HIV/AIDS Rep 2009; 6 : $63-7$

33. Dean GL, Edwards SG, Ives NJ et al. Treatment of tuberculosis in HIV-infected persons in the era of highly active antiretroviral therapy. AIDS 2002; 16 $75-83$.

34. Dheda K, Lampe FC, Johnson MA et al. Outcome of HIV-associated tuberculosis in the era of highly active antiretroviral therapy. J Infect Dis 2004; 190 $1670-6$.

35. World Health Organisation. Antiretroviral therapy for HIV infection in adults and adolescents. Genève: WHO, 2006

36. Folkehelseinstituttet. Revidert kapittel: 10.3. Behandling og forebygging av tuberkulose hos hivsmittede i Smittevern 7. www. fhi.no [19.5.2009).

37. Graybill JR, Sobel J, Saag M et al. Diagnosis and management of increased intracranial pressure in patients with AIDS and cryptococcal meningitis. Clin Infect Dis 2000; 30: 47-53.

38. King MD, Perlino CA, Cinnamon J et al. Paradoxial recurrent meningitis following therapy of cryptococcal meningitis: an immune reconstitution syndrome after initiation of highly active antiretroviral therapy. Int J STD AIDS 2002: 13: 724-6.

39. Burman WJ, Jones BE. Treatment of HIV-related tuberculosis in the era of effective antiretroviral therapy. Am J Respir Crit Care Med 2001; 164: $7-12$.

Manuskriptet ble mottatt 4.2. 2009 og godkjent 24.9. 2009. Medisinsk redaktør Åslaug Helland. 